\title{
Energy Balance, Metabolic Status, and the First Postpartum Ovarian Follicle Wave in Cows Administered Propylene Glycol
}

\author{
S. T. Butler, ${ }^{1}$ S. H. Pelton, and W. R. Butler ${ }^{2}$ \\ Department of Animal Science, Cornell University, Ithaca, NY 14853
}

\section{ABSTRACT}

Mature Holstein cows were drenched daily with either $500 \mathrm{~mL}$ of water (control; $\mathrm{n}=28$ ) or propylene glycol (PPG; $\mathrm{n}=28$ ) from $\mathrm{d} 10$ before parturition until d 25 postpartum. Follicular development was monitored thrice weekly by transrectal ultrasound. Blood samples were collected every 30 min from a subset of 10 cows per treatment on $\mathrm{d}-10,2$, and 25 to assess glucose and insulin response to treatments, and on $\mathrm{d} 10$ postpartum, blood was collected every 10 min for $12 \mathrm{~h}$ to determine LH pulse profiles. Both insulin and glucose were elevated on d 2 and 25 following PPG administration, but only insulin was elevated on $\mathrm{d}-10$. On $\mathrm{d} 10$ postpartum, the number of LH pulses, mean LH, and pulse amplitude were not different between control and PPG cows. The proportion of first postpartum dominant follicles that became ovulatory, atretic, or cystic was not different between control and PPG cows. Despite evidence of improved metabolic status, PPG failed to increase LH pulse frequency, and failed to increase the proportion of first postpartum follicle waves resulting in ovulation. The dominant follicle of each cow was retrospectively categorized as being ovulatory ( $\mathrm{n}=17)$, nonovulatory high estradiol $(\mathrm{n}=6)$, nonovulatory low estradiol ( $\mathrm{n}=$ $24)$, or cystic $(n=8)$. Differences in dry matter intake and energy balance among cows in the different follicle categories were apparent as early as $3 \mathrm{wk}$ before parturition. The nonovulatory low estradiol cows had lower pre- and postpartum dry matter intake and energy balance compared with ovulatory cows. The nonovulatory low estradiol cows also had postpartum metabolic hormone and metabolite profiles indicative of more severe negative energy balance.

Key words: cow, energy balance, ovulation, propylene glycol

\section{INTRODUCTION}

It is generally accepted that energy balance (EB), rather than intake of any specific class of nutrient, is the

\footnotetext{
Received July 5, 2005.

Accepted February 8, 2006.

${ }^{1}$ Present address: Teagasc, Moorepark Dairy Production Research Centre, Fermoy, Co. Cork, Ireland.

${ }^{2}$ Corresponding author: wrb2@cornell.edu
}

principal nutritional factor regulating the reproductive system (Butler and Smith, 1989; I'Anson et al., 1991; Wade et al., 1996). In dairy cattle, both the duration and severity of early postpartum negative energy balance (NEB) are correlated with the interval to resumption of ovulatory activity following parturition. The principal defect caused by NEB occurs at the level of the hypothalamus, manifested by reduced GnRH pulse frequency. The NEB results in a parallel reduction in pulsatile pituitary LH release, with consequent compromised follicular steroid output and anovulation. In addition, follicular responsiveness to gonadotropin stimulation is blunted by the circulating hormonal and metabolite environment of the NEB state. Moreover, hypothalamic responsiveness to the negative feedback effects of estradiol is enhanced, resulting in further attenuation of already suboptimal GnRH pulse frequency (for reviews see Beam and Butler, 1999; Wiltbank et al., 2002; Diskin et al., 2003). Collectively, these lesions result in anovulation for a varying period of time, with some cows remaining anestrous beyond 80 DIM. Prolonged anovulation is associated with reduced likelihood of conception (Darwash et al., 1997; Westwood et al., 2002; Butler 2003), and thus, a prompt return to cyclicity following parturition is desirable.

Several putative hormones, growth factors, and metabolites have been identified that are stimulatory or inhibitory to the reproductive axis. In general, these factors tend to increase and decrease in tandem during unfavorable nutritional conditions. Reduced circulating concentrations of insulin, IGF-I, leptin, and glucose, and elevated concentrations of BHBA, NEFA, and glucocorticoids are all associated with impaired reproductive performance. In contrast, there is an emerging paradigm that the lack of available metabolic fuels per se-rather than direct effects of hormones and metabolites-is responsible for the inhibition of reproduction during NEB (Wade et al., 1996; Schneider and Wade, 2000). The precise reason for reduced GnRH pulsatility is unknown, although it is clear that pulsatile $\mathrm{GnRH}$ release is sensitive to glucose availability (Bucholtz et al., 1996; Ohkura et al., 2004). Reduced circulating insulin and IGF-I do not seem to be involved in the suboptimal GnRH and LH pulse frequency, but elevated con- 
centrations of both are stimulatory to ovarian estradiol output (Butler et al., 2004).

Propylene glycol (1,2-propanediol; $\mathrm{C}_{3} \mathrm{H}_{8} \mathrm{O}_{2}$ ) is a sweet, hygroscopic, viscous liquid that has gluconeogenic properties and is routinely used because of its therapeutic effects on cows suffering from ketosis, based on the premise that it rapidly increases blood glucose. The current study was carried out to test the hypothesis that a daily increase in glucose and insulin, and reduction in NEFA, achieved via a daily propylene glycol (PPG) drench during the period from late pregnancy through the end of the first postpartum follicle wave would increase LH pulse frequency and the proportion of ovulatory first-wave follicles.

\section{MATERIALS AND METHODS}

\section{Cows and Treatments}

Based on expected calving date, parity, and previous 305-d milk yield, 56 multiparous Holstein cows were paired and assigned randomly to receive a daily 500 $\mathrm{mL}$ oral drench of either water (control) or PPG (Animal Medic Inc., Manchester, PA) from d 10 before expected parturition (d -10) until d 25 postpartum. A dose of 500 $\mathrm{mL}$ was chosen based on previous studies (Grummer et al., 1994; Miyoshi et al., 2001; Pickett et al., 2003). Drenching was carried out via consecutive use of 2 drenching guns (each $250 \mathrm{~mL}$ ). Cows were assigned to their experimental groups and treatments were initiated during a 5-mo period. To facilitate individual feed intake measurements, cows were housed in individual tie stalls starting on $\mathrm{d} 21$ before expected parturition, moved to individual box stalls for a 2 - to 4 -d period around the time of parturition, and then returned to individual tie stalls until d 30 postpartum. Weekly samples of the feed offered were dried and composited monthly for nutrient analysis (Dairy One Cooperative, Ithaca, NY). Ingredient and nutrient composition of the diets fed are summarized in Table 1.

Cows were fed daily at $0900 \mathrm{~h}$ and drenched at 1500 h. Drenching at $1500 \mathrm{~h}$ was chosen in an effort to extend postprandial increases in circulating glucose and insulin. Following parturition, cows were milked 3 times daily at 0030,0830 and $1630 \mathrm{~h}$. During the period from d -21 until d 0 (i.e., day of parturition), blood samples were collected from all cows on Monday, Wednesday, and Friday, and then daily from parturition until d 25 postpartum. These blood samples were collected at 1200 $\mathrm{h}$ from the coccygeal vessels using vacutainers containing sodium heparin (Becton Dickinson, Franklin Lakes, NJ). A subset of 10 cows from each treatment was selected for periods of more intensive blood sampling and liver biopsies. More frequently obtained blood samples were collected via an indwelling jugular cathe-
Table 1. Ingredient and nutrient composition of prepartum and postpartum diets

\begin{tabular}{|c|c|c|}
\hline Ingredient (\% of DM) & Prepartum & Postpartum \\
\hline Corn silage & 29.8 & 23.2 \\
\hline Legume haylage & 14.7 & 15.7 \\
\hline Alfalfa hay & 17.0 & 8.4 \\
\hline Cornmeal & - & 19.0 \\
\hline High-moisture shelled corn & 25.2 & 7.8 \\
\hline Soybean meal & 4.9 & 7.6 \\
\hline Homermeal $^{1}$ & 4.9 & 6.4 \\
\hline Whole cottonseed & - & 6.0 \\
\hline Yeast culture $^{2}$ & 0.9 & - \\
\hline Ca-salts of long chain fatty acids ${ }^{3}$ & - & 1.9 \\
\hline Urea $(45 \% \mathrm{~N})$ & - & 0.2 \\
\hline Mineral and vitamin premix ${ }^{4,5}$ & 2.5 & 1.4 \\
\hline Sodium bicarbonate & - & 1.3 \\
\hline Limestone & - & 0.5 \\
\hline Biophos $^{6}$ & - & 0.2 \\
\hline White salt & - & 0.5 \\
\hline \multicolumn{3}{|l|}{ Nutrient composition (DM basis) } \\
\hline $\mathrm{NE}_{\mathrm{L}}, \mathrm{Mcal} / \mathrm{kg}$ & 1.63 & 1.73 \\
\hline $\mathrm{NDF}, \%$ & 34.0 & 29.0 \\
\hline NFC, \% & 33.3 & 38.5 \\
\hline Starch, \% & 25.1 & 23.5 \\
\hline Crude fat, $\%$ & 4.4 & 6.1 \\
\hline $\mathrm{CP}, \%$ & 16.4 & 18.3 \\
\hline Lignin, \% & 5.4 & 4.8 \\
\hline $\mathrm{Ca}, \%$ & 0.88 & 1.03 \\
\hline $\mathrm{P}, \%$ & 0.43 & 0.44 \\
\hline $\mathrm{K}, \%$ & 1.36 & 1.29 \\
\hline $\mathrm{Mg}, \%$ & 0.32 & 0.32 \\
\hline
\end{tabular}

${ }^{1}$ Hi-bypass soybean meal, Homer Oil Co., Homer, NY.

${ }^{2}$ Diamond V XP, Cedar Rapids, IA.

${ }^{3}$ Megalac, Church and Dwight Co., Inc., Princeton, NJ.

${ }^{4}$ Prepartum mineral and vitamin mix (per kilogram of mix): $16.5 \%$ $\mathrm{Ca}, 3 \% \mathrm{P}, 5 \% \mathrm{Mg}, 0.3 \% \mathrm{~K}, 5 \% \mathrm{Na}, 8 \% \mathrm{Cl}, 8 \% \mathrm{~S}, 35 \mathrm{ppm} \mathrm{Co}, 450 \mathrm{ppm}$ $\mathrm{Cu}, 3,700$ ppm Fe, 50 ppm I, 3,100 ppm Mn, 3,500 ppm Zn, 10 ppm Se, 330,000 IU/kg vitamin A, 88,000 IU/kg vitamin D, 1,800 IU/kg vitamin $\mathrm{E}$.

${ }^{5}$ Postpartum mineral and vitamin premix (per kilogram of mix): $11.2 \% \mathrm{Ca}, 8.0 \% \mathrm{Mg}, 1.0 \% \mathrm{~K}, 13.2 \% \mathrm{Na}, 20 \% \mathrm{Cl}, 8 \% \mathrm{~S}, 57 \mathrm{ppm} \mathrm{Co}$ 800 ppm Cu, 2,000 ppm Fe, 90 ppm I, 5,400 ppm Mn, 6,200 ppm Zn, $20 \mathrm{ppm}$ Se, 550,000 IU/kg vitamin A, 130,000 IU/kg vitamin D, 3,000 IU/kg vitamin $\mathrm{E}$.

${ }^{6}$ Agrico Feed Ingredients Products, New Wales, FL.

ter (Tygon Microbore Tubing, Norton Performance Plastic, Akron, $\mathrm{OH})$ on $\mathrm{d}-10 \pm 1.2($ mean $\pm \mathrm{SEM}), \mathrm{d} 2$, and $\mathrm{d} 25$ relative to parturition $(8 \mathrm{~mL}$ every $30 \mathrm{~min}$ from 0900 to $2100 \mathrm{~h}$ ) and on d 10 postpartum $(4 \mathrm{~mL}$ every 10 min from 0900 to $2100 \mathrm{~h}$ ). All catheters were inserted the day before frequent blood collection. Heparinized blood samples were centrifuged at $2,060 \times g$, plasma was harvested, and stored at $-20^{\circ} \mathrm{C}$ for subsequent hormone and metabolite analyses. All procedures involving animals were approved by the Cornell University Institutional Animal Care and Use Committee.

\section{Plasma Hormone and Metabolite Analysis}

Plasma samples collected thrice weekly prepartum and daily after parturition were analyzed for estradiol- 
$17 \beta$, insulin, IGF-I, glucose, NEFA, and BHBA. All frequently collected blood samples from $\mathrm{d}-10,2$, and 25 relative to parturition were analyzed for insulin, glucose, and NEFA. All blood samples collected at 10-min intervals on d 10 postpartum were analyzed for $\mathrm{LH}$. Circulating estradiol concentrations collected between parturition and d 25 postpartum were measured by radioimmunoassay (Serono Maia, Cortlandt Manor, NY) by the procedure of Butler et al. (2004). Insulin and glucose concentrations were determined in 3 samples collected during the period from $\mathrm{d}-10$ to 0 (approximately $d-9,-6$, and -3 ), and every other day from parturition until d 24 postpartum. Insulin was measured by a double-antibody radioimmunoassay (Linco Research Inc., St. Louis, MO) as described by McGuire et al. (1995). Concentration of IGF-I in samples collected on $\mathrm{d}-7$ (approximately), 0, 5, 15, and 25 relative to parturition were measured following ethanol-acetone-acetic acid (60:30:10) extraction as described by Butler et al. (2004). Plasma LH concentrations were determined in all blood samples collected on d 10 postpartum and LH pulses were identified (Butler et al., 2004). Inter- and intraassay coefficients of variation were 16.7 and $8.2 \%, 4.5$ and $6.1 \%, 15.4$ and $5.2 \%$, and 8.1 and $2.3 \%$, for estradiol $(\mathrm{n}=21)$, insulin $(\mathrm{n}=10)$, IGF-I $(\mathrm{n}=3)$, and LH $(\mathrm{n}=3)$, respectively.

Concentrations of NEFA were determined in 3 prepartum samples (approximately $\mathrm{d}-9,-6$, and -3 ), daily from parturition until $\mathrm{d} 3$ postpartum, and every third day thereafter until d 24 postpartum. Plasma BHBA concentrations were measured in 3 prepartum samples (approximately d $-9,-6$, and -3 ), and every third day from parturition until d 24 postpartum.

Plasma metabolites were analyzed by enzymatic colorimetric assays using procedures modified from available kits [glucose (kit 510A) and BHBA (kit 310-UV), Sigma-Aldrich Co., St. Louis, MO; NEFA, Wako Chemicals USA Inc., Dallas, TX] and validated in our laboratory. Analyses of glucose, NEFA, and BHBA were conducted in 96-well microplates (Becton Dickinson) and read using a microplate reader (EL340, BioTek Instruments, Winooski, VT).

\section{Liver Tissue Collection and Triglyceride Determination}

Liver tissue was collected from 10 cows per treatment on d 5 and 25 following parturition as previously described (Butler et al., 2003). Tissue was rinsed in saline and blotted dry, snap-frozen in liquid nitrogen, and stored at $-80^{\circ} \mathrm{C}$. Tissue (approximately $150 \mathrm{mg}$ ) was homogenized with a polytron in chloroform and methanol (2:1) for about $10 \mathrm{~s}$, total lipids were extracted (Folch et al., 1957), and triglyceride (TG) concentration was determined by a colorimetric Hantzsch condensation method (Foster and Dunn, 1973) using glycerol trioleate (T-7140; Sigma-Aldrich Co.) to generate a standard curve. Inter- and intraassay $(\mathrm{n}=4)$ coefficients of variation were 8.4 and $6.2 \%$, respectively.

\section{Ovarian Ultrasonography}

Ovarian follicular activity of all cows was examined by linear array ultrasonography (7.5-MHz transrectal transducer, Aloka 210, Corometrics Medical Systems Inc., Wallingford, CT) thrice weekly (Monday, Wednesday, and Friday) beginning on d 8 to 10 postpartum and continuing until ovulation, or until d 30 for cows failing to ovulate. Diameter of dominant follicles between ultrasound examinations was calculated by linear interpolation. Follicles were considered to be dominant when a diameter of $>10 \mathrm{~mm}$ was reached in the absence of other large, growing follicles (Savio et al., 1990). An exception to this rule occurred when codominant follicles were observed. In this instance, diameter of the largest codominant follicle was reported. Cysts were defined as anovulatory follicles $>25 \mathrm{~mm}$ in diameter that persisted for at least $10 \mathrm{~d}$ in the absence of a corpus luteum (Garverick, 1997).

\section{EB Determination}

Energy intake was computed based on daily measurements of DMI and the calculated NEL value of the diet (Dairy One Cooperative). Maintenance requirements were calculated based on weekly BW measurements. Energy requirements for pregnancy were based on day of gestation. Lactation requirements were based on daily measurements of milk yield, and weekly measurements of milk composition (fat, protein, and lactose). Individual estimates of daily EB were calculated as the difference between energy intake and energy requirements (NRC, 2001). Duration of declining EB was calculated as the time from the onset of declining EB until day of EB nadir.

\section{Statistical Analyses}

Data were analyzed using SAS (SAS Inst. Inc., Cary, NC). Daily measurements of DMI and EB made during the period from $\mathrm{d}-21$ to -11 relative to parturition (i.e., before onset of treatments), or measurements of plasma insulin, glucose, and NEFA made during the 6 -h period before drenching on days of frequent blood collection were used for covariate adjustments. Hormone, metabolite, liver TG, and production data were analyzed as repeated measures using the MIXED procedure. To ac- 
commodate the requirements of nonlinear analysis using the MIXED procedure, common prepartum sampling days are needed among experimental units. Therefore, the blood samples selected for analyses of hormones and metabolites were as close as possible to the days selected for statistical analysis (e.g., $d-9,-6$, and -3). Fixed effects included experimental treatment, time (days or hours), and their interaction. Cow within treatment was used as a random effect, with day or hour as the repeated statement, using a first-order autoregressive plus random effect covariance structure (Littell et al., 1998). When the interaction between treatment and time was significant $(P<0.05)$, pairwise comparisons of individual means were carried out using the Tukey-Kramer test. The LH data were analyzed using a one-way ANOVA test.

The data were also analyzed by grouping cows on the basis of dominant follicle outcome and corresponding circulating estradiol profiles irrespective of treatment into 4 categories: ovulatory $(\mathbf{O V} ; \mathrm{n}=17)$, nonovulatory high estradiol (NH; $\mathrm{n}=6$ ), nonovulatory low estradiol $(\mathbf{N L} ; \mathrm{n}=24)$, and cyst $(\mathbf{C Y S} ; \mathrm{n}=8)$. Analysis was carried out using the MIXED procedure as described above, with the exception that follicle type was used in the model instead of treatment, cow within follicle type was the random variable, and the data were not subjected to covariate adjustment. When the interaction between follicle type and time was significant $(P<0.05)$, pairwise comparisons of individual means were carried out using the Tukey-Kramer test. The DMI and EB profiles were divided into 3 periods for analysis purposes: $d-21$ to $-8, \mathrm{~d}-7$ to -1 , and $\mathrm{d} 0$ to 30 relative to parturition. Hormone and metabolite data were separated into prepartum, postpartum, and combined pre- and postpartum data sets for analysis. Blood glucose on the day of parturition was analyzed using PROC MIXED with follicle type in the model, and cow within follicle type as the random variable. Pre- and postpartum DMI, EB, circulating insulin, IGF-I, glucose, and NEFA values were compared between OV cows and the mean of all other cows $(\mathrm{NH}+\mathrm{NL}+\mathrm{CYS})$ using the ESTIMATE statement in the MIXED procedure. Liver TG data were available for 5 ovulatory and 15 nonovulatory cows. To minimize the large observed variance in liver TG concentrations, difference in hepatic TG accumulation between $\mathrm{d} 5$ and 25 was compared for $\mathrm{OV}$ and nonovulatory cows using a paired $t$-test. Multiple logistic regression using the LOGISTIC procedure of SAS, with the SELECTION=SCORE option in the model statement to generate optimum subset models, was carried out to identify the independent variables that were most effective for predicting ovulation. Cows with an ovulatory follicle were coded 1 , and all other cows were coded 0 . For illustrative purposes, EB curves were smoothed using PROC LOESS with a smoothing parameter of 0.2 . Significance was declared at $P<0.05$, and trends from $P=0.05$ to $P<0.15$.

\section{RESULTS}

\section{DMI, Milk Yield, and Milk Composition}

Effects of drenching with water or PPG on DMI, milk yield, and milk composition are summarized in Table 2. No treatment effect was detected for DMI, milk yield, or milk protein concentration. Milk fat concentration tended ( $P=0.07)$ to be reduced in response to PPG, and milk lactose concentration was increased $(P<0.05)$. After adding the energetic value of $500 \mathrm{~mL}$ of PPG (2 $\mathrm{Mcal}$ ) to dietary energy consumed, a significant beneficial effect of PPG on EB was observed (Table 2).

\section{Hormones, Metabolites, and Liver TG}

Effect of drenching with water or PPG on the mean concentrations of glucose, insulin, and NEFA in samples collected at 30-min intervals during the $6 \mathrm{~h}$ postdrenching period on $\mathrm{d}-10,2$, and 25 relative to parturition is summarized in Table 3. Plasma insulin was increased $(P<0.01)$ or tended $(P \leq 0.08)$ to increase in response to drenching with PPG at all time points. Glucose was increased $(P<0.01)$ and NEFA was decreased $(P<0.05)$ in response to a PPG drench postpartum, but not prepartum.

In blood samples collected at $1200 \mathrm{~h}$ through the transition period ( $3 \mathrm{~h}$ before daily drenching), prepartum insulin concentrations were initially lower at about $d$ 10 prepartum, but postpartum concentrations were greater in cows given PPG (treatment $\times$ time interaction, $P<0.05$; Figure 1). Circulating glucose tended $(P=0.096)$ to be greater (Figure 1), whereas plasma NEFA $(P<0.05)$ and BHBA $(P<0.01)$ were reduced in response to PPG (Figure 2). Drenching with PPG tended $(P=0.08)$ to reduce postpartum hepatic TG concentration (Figure 3).

\section{Follicular Development and LH Pulse Data}

Effects of drenching with water or PPG on the fate and characteristics of the first postpartum follicle wave are summarized in Table 4. No difference between treatments was detected in the number of cows with follicles ovulating, undergoing atresia, or becoming cystic. Within these 3 possible outcomes, no treatment effect was detected for maximum diameter of the dominant follicle, peak plasma estradiol concentration, or day of peak plasma estradiol concentration. Day of maximum follicle diameter was earlier $(P<0.05)$ in nonovulatory cows drenched with PPG. No effect of the PPG 
Table 2. Effect of drenching with water (control) or propylene glycol (PPG) on DMI, milk yield, and milk composition during the transition period

\begin{tabular}{lcccc}
\hline & \multicolumn{2}{c}{ Treatment } & & \\
\cline { 2 - 3 } Item & Control & PPG & SEM & $P$-value \\
\hline Day -10 to -1 prepartum & & & & \\
DMI, kg/d & 14.0 & 13.4 & 0.3 & 0.16 \\
Energy balance, Mcal/d & 6.2 & 7.3 & 0.4 & 0.08 \\
Day 0 to 30 postpartum & & & & 0.3 \\
DMI, kg/d & 19.5 & 18.7 & 0.5 & 0.009 \\
Energy balance, Mcal/d & -11.4 & -9.4 & 0.5 & 0.071 \\
Milk yield, kg/d & 44.9 & 44.3 & 0.09 & 0.8 \\
Milk fat, \% & 4.47 & 4.23 & 0.08 & 0.027 \\
Milk protein, \% & 3.21 & 3.23 & & 0.04 \\
Milk lactose, \% & 4.62 & 4.74 & & \\
\hline
\end{tabular}

drench was detected for LH pulse frequency, LH pulse amplitude, or mean circulating LH measured in blood samples collected frequently on d 10 postpartum (Table 4). These data also were analyzed by paired $t$-test within cow comparing the LH pulse data for the 6 -h periods before and after drenching. No treatment differences were observed (data not shown).

\section{Grouping of Follicles by Growth Pattern and Estradiol Output}

Cows were grouped based on growth and fate of the first postpartum follicle wave and the associated circulating estradiol profiles. One cow had ambiguous follicular and estradiol data and was excluded from the analysis, leaving a total of 55 cows. Of these, 17 had OV dominant follicles, 6 had NH dominant follicles, 24 had NL dominant follicles, and 8 cows had dominant follicles that developed into CYS.

All 17 of the OV cows exhibited a preovulatory rise in circulating estradiol (range 3.4 to $8.0 \mathrm{pg} / \mathrm{mL}$ ) and ovulation of either a single dominant follicle $(\mathrm{n}=12)$ or 2 codominant follicles $(\mathrm{n}=5)$. The $6 \mathrm{NH}$ cows had a preovulatory-like rise in estradiol that exceeded $4.0 \mathrm{pg} /$ $\mathrm{mL}$ (range 4.5 to $7.1 \mathrm{pg} / \mathrm{mL}$ ), followed by either an abrupt reduction to about $1 \mathrm{pg} / \mathrm{mL}$ within $24 \mathrm{~h}(\mathrm{n}=3)$, or a slower reduction during a 3- to 4 -d period ( $\mathrm{n}=$ 3). Pattern of follicle growth of the 24 NL cows was associated with low circulating estradiol; a distinct peak in estradiol was not evident, and the mean circulating estradiol on the day of maximum follicle diameter was $0.9 \mathrm{pg} / \mathrm{mL}$ (range 0.3 to $2.7 \mathrm{pg} / \mathrm{mL}$ ). Among the 24 NL cows, the large follicle exerted dominance in 20 cows and a new wave did not commence until the first dominant follicle started to regress. Conversely, in 4 NL cows, the large follicle failed to exert dominance, and a new wave of follicle growth emerged while the existing dominant follicle was still growing, such that a second wave dominant follicle with a diameter of 12.4 $\pm 1.2 \mathrm{~mm}$ (range 9.5 to $15.5 \mathrm{~mm}$ ) was present on the ovary on the day that the first-wave follicle reached its maximum diameter. In 6 of the 8 CYS cows that were observed, the large follicle produced high circulating concentrations of estradiol (peak estradiol $=12.5 \pm 2.7$

Table 3. Effect of drenching with water (control) or propylene glycol (PPG) on mean circulating concentration of glucose, insulin and NEFA for $6 \mathrm{~h}$ postdrenching on $\mathrm{d}-10,2$, and 25 relative to parturition

\begin{tabular}{|c|c|c|c|c|c|}
\hline & \multirow{2}{*}{\multicolumn{2}{|c|}{ Treatment }} & \multirow[b]{3}{*}{ SEM } & \multicolumn{2}{|c|}{$P$-value } \\
\hline & & & & & Treatment \\
\hline & Control & PPG & & Treatment & $\times$ time \\
\hline \multicolumn{6}{|l|}{ Glucose, $\mathrm{mg} / \mathrm{dL}$} \\
\hline $\mathrm{d}-10$ & 61.5 & 62.1 & 1.1 & 0.7 & 0.6 \\
\hline $\mathrm{d} 2$ & 46.6 & 52.3 & 1.3 & 0.007 & 0.001 \\
\hline $\mathrm{d} 25$ & 52.4 & 56.8 & 0.7 & 0.001 & 0.001 \\
\hline \multicolumn{6}{|l|}{ Insulin, $\mathrm{ng} / \mathrm{mL}$} \\
\hline $\mathrm{d}-10$ & 1.45 & 1.71 & 0.10 & 0.09 & 0.07 \\
\hline d 2 & 0.34 & 0.47 & 0.05 & 0.08 & 0.15 \\
\hline d 25 & 0.53 & 0.68 & 0.04 & 0.008 & 0.001 \\
\hline \multicolumn{6}{|l|}{$\mathrm{NEFA}, \mu \mathrm{mol} / \mathrm{L}$} \\
\hline $\mathrm{d}-10$ & 100 & 97 & 6 & 0.7 & 0.4 \\
\hline d 2 & 514 & 391 & 31 & 0.012 & 0.009 \\
\hline d 25 & 306 & 205 & 30 & 0.026 & 0.001 \\
\hline
\end{tabular}



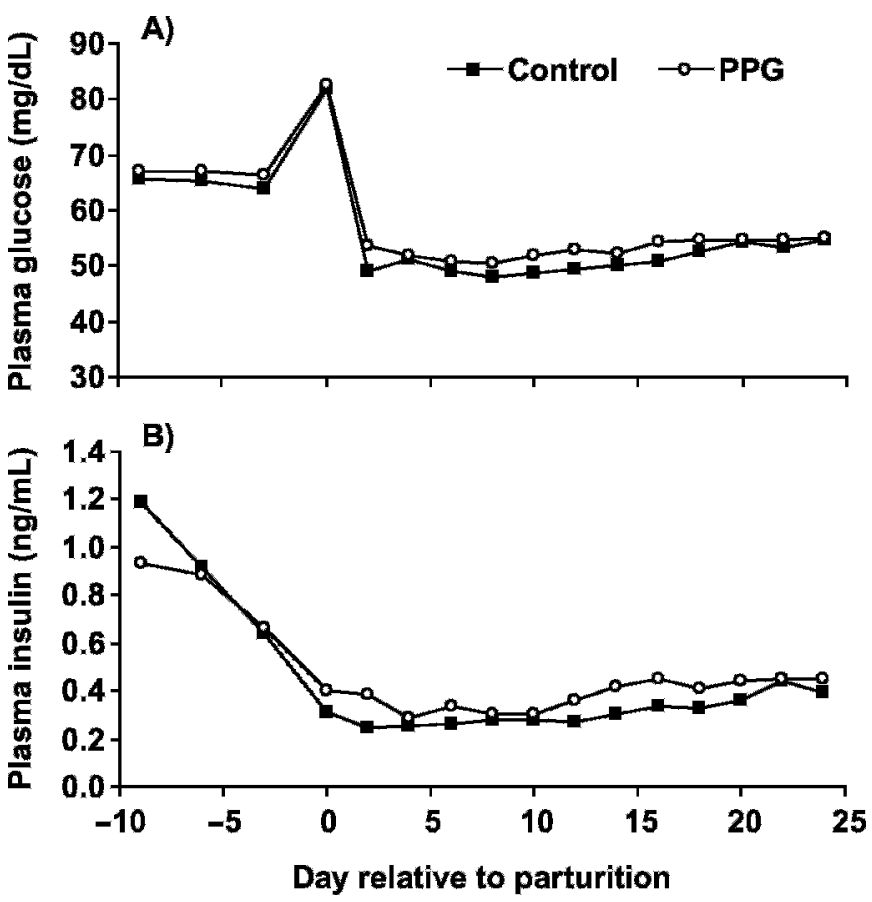

Figure 1. Circulating concentrations of insulin and glucose during the transition period in cows drenched with either $500 \mathrm{~mL}$ of water (control) or $500 \mathrm{~mL}$ of propylene glycol (PPG). Samples were collected before drenching. A) Concentration of glucose in plasma was determined by an enzymatic assay in 3 prepartum samples and every other day postpartum. Circulating glucose tended $(P=0.10)$ to be greater in PPG-treated cows (pooled SEM $=0.83 \mathrm{mg} / \mathrm{dL}$ ) than in control animals. No treatment $\times$ time effect was detected. B) Plasma insulin concentrations were determined by radioimmunoassay in 3 prepartum samples, and every other day postpartum. A significant treatment $\times$ time effect was observed $(P<0.05$; pooled SEM $=0.028$ $\mathrm{ng} / \mathrm{mL}$ ), but no effect of treatment.

$\mathrm{pg} / \mathrm{mL}$ ) and exerted dominance, as evidenced by preventing new follicular wave emergence. In the remaining 2 CYS cows, preovulatory-like estradiol concentrations (peak estradiol $=4.7 \pm 0.1 \mathrm{pg} / \mathrm{mL}$ ) were produced, and estradiol then declined abruptly. These preovulatory-like estradiol peaks were observed on $d$ 15 and 18 postpartum, with corresponding follicle diameters of 18 and $25 \mathrm{~mm}$, respectively. The dominant follicles continued to grow and develop into cysts, but another wave of follicular growth commenced 3 to $4 \mathrm{~d}$ later in the presence of the developing cyst. Profiles of follicular development and circulating estradiol for 6 individual representative cows are illustrated in Figure 4.

\section{Relationship Among Follicle Type, EB, DMI, and Metabolic Status}

Follicle characteristics are summarized in Table 5, and $\mathrm{EB}$, hormone, and metabolite measurements for the different follicle types are illustrated in Figures 5
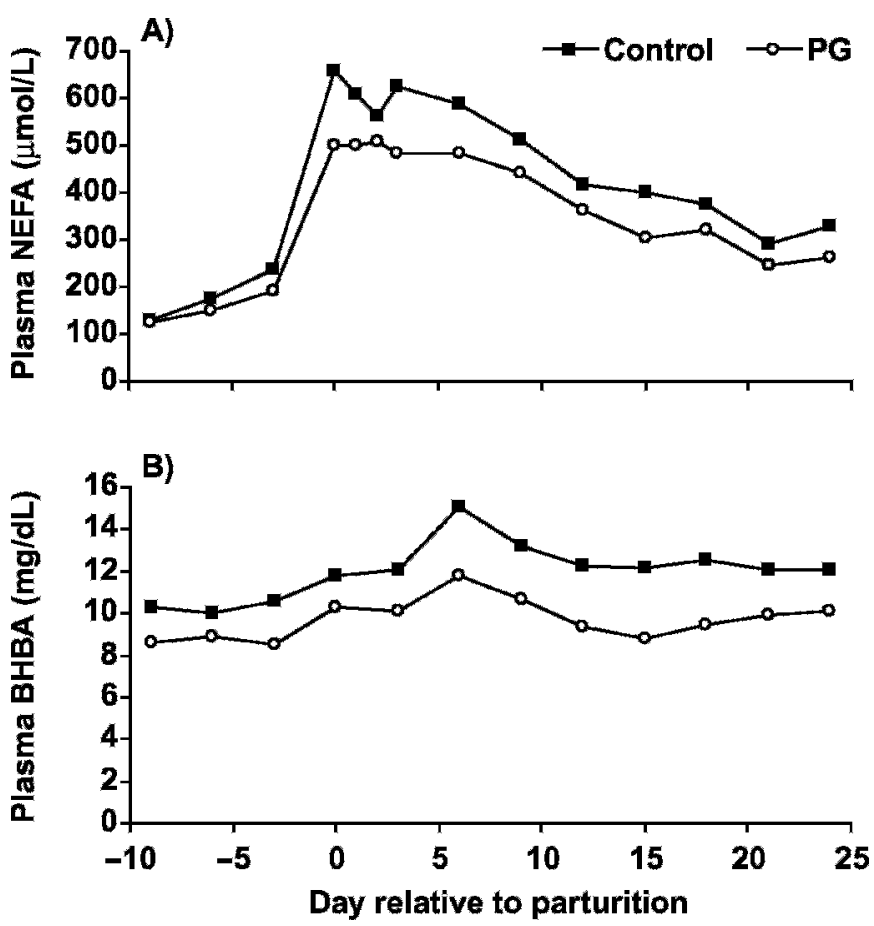

Figure 2. Circulating concentrations of NEFA and BHBA during the transition period in cows drenched with either $500 \mathrm{~mL}$ of water (control) or $500 \mathrm{~mL}$ of propylene glycol (PPG). Samples were collected before drenching. A) Plasma NEFA concentrations were determined by enzymatic assay in 3 prepartum samples, daily from parturition until d 3 postpartum, and every third day thereafter. A significant treatment effect was observed $(P<0.05$; pooled SEM $=21.4 \mu \mathrm{mol} /$ L). No treatment $\times$ time interaction was detected. B) Plasma BHBA concentrations were determined using an enzymatic assay in 3 prepartum samples, at parturition, and every third day thereafter. A significant treatment effect was observed $(P<0.01$; pooled SEM $=$ $0.56 \mathrm{mg} / \mathrm{dL}$ ), but no treatment $\times$ time interaction was detected.

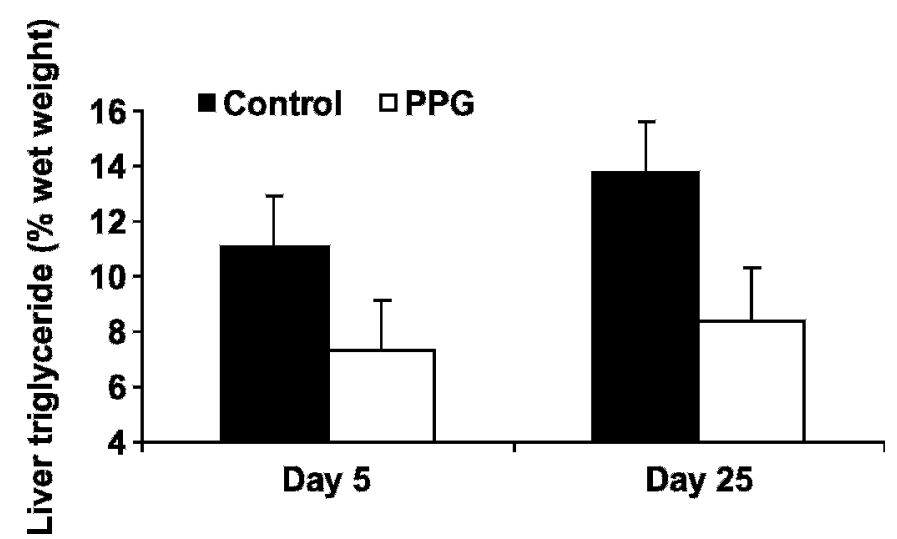

Figure 3. Triglyceride concentration in liver tissue collected on d 5 and 25 postpartum in dairy cows $(\mathrm{n}=10$ per treatment) drenched with either $500 \mathrm{~mL}$ of water (control) or $500 \mathrm{~mL}$ of propylene glycol (PPG). Cows were drenched from d -10 to 25 . Triglyceride concentration tended $(P=0.08)$ to be less in PPG-treated cows than in control cows (pooled SEM $=1.89 \%$ ). 
Table 4. Characteristics associated with dominant follicles of the first postpartum follicle wave after drenching with water (control) or propylene glycol (PPG)

\begin{tabular}{lcccc}
\hline & \multicolumn{2}{c}{ Treatment } & & \\
\cline { 2 - 3 } Item & Control & PPG & SEM & $P$-value \\
\hline Ovulatory, n & 9 & 8 & - & - \\
Peak plasma estradiol, pg/mL & 5.8 & 5.9 & 0.48 & 0.9 \\
Day of peak estradiol & 15.1 & 17.4 & 1.6 & 0.3 \\
Peak follicle diameter, mm & 18.6 & 17.5 & 1.2 & 0.5 \\
Day of peak follicle diameter & 16.6 & 17.9 & 1.6 & 0.6 \\
Nonovulatory (atretic), 1 n & 15 & 16 & - & - \\
Estradiol at peak follicle diameter, pg/mL & 2.3 & 2.1 & 0.6 & 0.8 \\
Peak follicle diameter, mm & 16.8 & 16.5 & 0.9 & 0.8 \\
Day of peak follicle diameter & 21.7 & 19.0 & 0.9 & 0.046 \\
Cystic, n & 4 & 4 & - & - \\
Peak plasma estradiol, pg/mL & 12.4 & 8.8 & 3.4 & 0.5 \\
Day of peak estradiol & 19.0 & 19.5 & 1.2 & 0.8 \\
Peak follicle diameter, mm & 31.5 & 30.5 & 2.3 & 0.8 \\
Day of peak follicle diameter & 27.3 & 29.3 & 1.5 & 0.4 \\
LH pulse characteristics on d 10 postpartum & & & & \\
Pulse frequency, number/12 h & 7.8 & 7.1 & 0.5 & 0.4 \\
Pulse amplitude, ng/mL & 0.56 & 0.50 & 0.07 & 0.5 \\
Mean LH, ng/mL & 0.56 & 0.46 & 0.05 & 0.2 \\
\hline
\end{tabular}

${ }^{1} \mathrm{~A}$ clear peak in plasma estradiol was not apparent for most cows in the atretic group; the value on the day of peak dominant follicle diameter is reported, and day of peak estradiol is omitted.

to 8 . No differences were detected among follicle-type groups in milk yield $(44.3 \pm 0.3 \mathrm{~kg} / \mathrm{d})$, and differences in EB were reflected by differences in DMI (Table 6). When compared with all nonovulatory cows $(\mathrm{NH}+\mathrm{NL}$ + CYS), OV cows had superior prepartum (final week) and postpartum DMI and EB, greater $(P<001)$ postpartum insulin, and tended $(P<0.1)$ to have greater postpartum glucose and IGF-I. This was primarily because of significant differences between OV and NL cows for all these variables, with CYS cows only differing $(P<$ 0.05 ) from $\mathrm{OV}$ cows for glucose on day of parturition (103.6 vs. $70.7 \mathrm{mg} / \mathrm{dL}$; OV vs. CYS, respectively) and tending $(P=0.06)$ to have lower postpartum insulin ( 0.43 vs. $0.34 \mathrm{ng} / \mathrm{mL}$ ). The NH cows were not different from OV cows for any of the variables measured with the exception of tending $(P=0.10)$ to have less postpartum concentrations of insulin ( 0.43 vs. $0.34 \mathrm{ng} / \mathrm{mL}$ ), and having greater DMI and superior EB during late pregnancy ( $\mathrm{d}-21$ to -8$)$. Within the group of cows that developed nonovulatory follicles, $\mathrm{NH}$ cows had greater $(P<0.001)$ prepartum $(\mathrm{d}-21$ to -8$) \mathrm{EB}$ and DMI than NL or CYS, but postpartum differences were not significant (Table 6). Compared with OV cows, NH cows had a more gradual decrease $(P<0.001)$ to $\mathrm{EB}$ nadir (duration of decrease in $\mathrm{EB}=10.4 \pm 1.6$ vs. $24.2 \pm 2.7$ d; Figure 5). Compared with OV cows, NL cows had lower prepartum $(P<0.05)$ and postpartum $(P<0.005)$ DMI, and had less $(P<0.05)$ positive prepartum and more $(P<0.001)$ negative postpartum EB (Table 6$)$. Furthermore, the NL cows also had postpartum metabolic hormone and metabolite profiles indicating more severe NEB [insulin, 0.43 vs. $0.30 \mathrm{ng} / \mathrm{mL}(P<0.001)$; IGF-I, 63 vs. $41 \mathrm{ng} / \mathrm{mL}(P<0.05)$; NEFA, 381 vs. 495 $\mu \mathrm{mol} / \mathrm{L}(P<0.05) ;$ OV vs. NL, respectively]. Of the cows that developed cysts, the 2 cows that had an abrupt decline in estradiol seemed to have more $(P<0.05)$ favorable EB (average d -21 to $30: 0.7 \pm 1.7$ vs. $-4.3 \pm$ $1.0 \mathrm{Mcal} / \mathrm{d}$ ), but the small number of cows having that type of follicle profile prohibited meaningful and reliable analysis. Of note, the glucose to insulin ratio was lowest in OV cows $(46.0 \pm 3.5)$ and highest in the NL cows $[68.7 \pm 2.9$; OV vs. NL $(P<0.001)]$, with NH $[57.5$ \pm 5.7 ; OV vs. $\mathrm{NH}(P=0.09)$; NH vs. NL $(P=0.08)]$ and CYS $[55.9 \pm 4.9$; OV vs. CYS $(P=0.1)$; CYS vs. NL $(P$ $<0.05$ )] cows being intermediate (Figure 6 ). Liver TG concentration was not different on d 25 compared with d 5 in cows with an OV follicle (from $8.5 \pm 3.0 \%$ on d 5 to $7.5 \pm 2.5 \%$ on $\mathrm{d} 25$ ), but TG concentration tended $(P=0.08)$ to increase in nonovulatory cows during the same interval (from $9.4 \pm 1.4 \%$ on $d 5$ to $11.5 \pm 1.7 \%$ on $\mathrm{d} 25$ ).

The multiple logistic regression model for predicting likelihood of an ovulatory follicle is outlined in Table 7. The predictors that the SCORE variable selection procedure selected were duration of declining EB, postpartum plasma insulin concentration, DMI in the final week before parturition, and plasma glucose on day of parturition. When all individual cow-pairs having different responses (i.e., all possible 0 and 1 combinations) were analyzed by this model, the cow with an ovulatory follicle was correctly identified in $92.9 \%$ of the cases. 

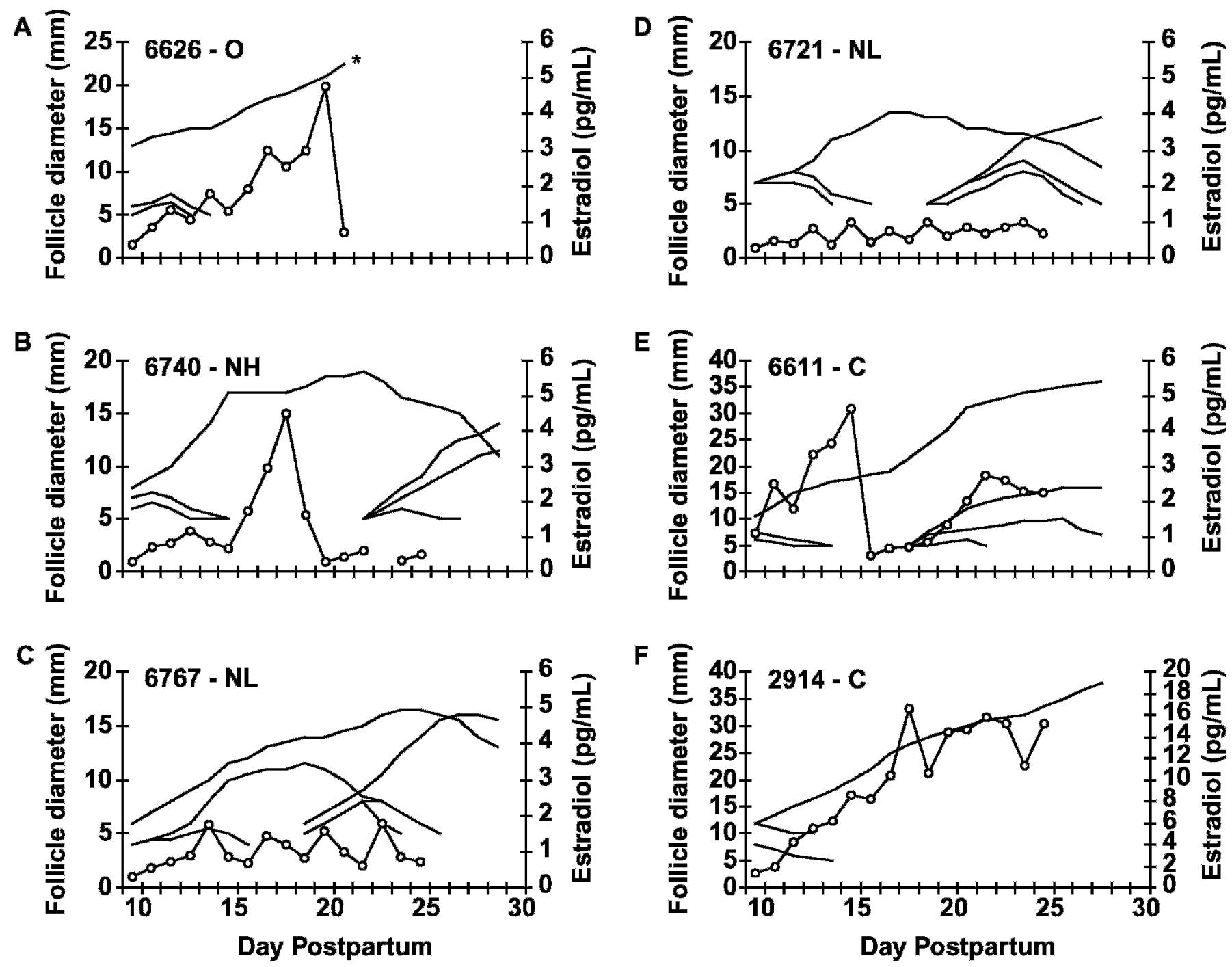

Figure 4. Patterns of follicular growth (solid lines) and circulating estradiol (lines with open circles) during the first postpartum follicle wave. A) Growth of a single dominant follicle with a preovulatory rise in estradiol followed by an abrupt decline, and ovulation (*) of the dominant follicle; B) growth of a single dominant follicle with a preovulatory-like rise in estradiol followed by a rapid reduction in estradiol, failure of the dominant follicle to ovulate, and emergence of a new follicle wave while the first-wave dominant follicle underwent atresia; C) a nonovulatory first-wave dominant follicle that failed to exert dominance. The second wave emerged while the first-wave dominant follicle was still growing with no evidence of a preovulatory-like rise in estradiol; D) a nonovulatory first-wave dominant follicle that exerted dominance and prevented emergence of a new wave until first-wave dominant follicle started to regress. No evidence of a preovulatory-like rise in estradiol; E) growth of a single dominant follicle, a preovulatory-like rise in estradiol followed by a rapid reduction, failure of the dominant follicle to ovulate, and rather than regressing, the follicle continued to grow and develop into a cyst. A new wave emerged approximately $3 \mathrm{~d}$ after the peak of the preovulatory-like rise in estradiol and continued to grow in the presence of the developing cyst; F) growth of a single dominant follicle, a preovulatory-like rise in estradiol followed by a further increase in estradiol to beyond typical LH surge inducing concentrations, failure of the dominant follicle to ovulate, and rather than regressing, the follicle continued to grow and develop into a cyst. Estradiol concentrations remained elevated, and emergence of a new follicle wave was not observed.

\section{DISCUSSION}

Propylene glycol is a glucogenic precursor that is either rapidly absorbed from the rumen and converted to glucose, or partially metabolized to propionate in the rumen before being absorbed (Nielsen and Ingvartsen, 2004). As outlined in Table 3, drenching with PPG re- sulted in increased plasma glucose and insulin concentrations and reduced NEFA concentrations, in agreement with previous studies (Studer et al., 1993; Grummer et al., 1994). In agreement with the findings of Christensen et al. (1997), PPG was more effective at increasing blood glucose and reducing plasma NEFA during NEB (lactation) than during positive EB (preg- 
Table 5. Summary of dominant follicle development and estradiol production in cows grouped on the basis of follicle type observed during the first postpartum wave

\begin{tabular}{|c|c|c|c|c|c|}
\hline \multirow[b]{2}{*}{ Item } & \multicolumn{4}{|c|}{ Follicle type $^{1}$} & \multirow[b]{2}{*}{$P$-value } \\
\hline & $\begin{array}{l}\text { OV } \\
(\mathrm{n}=17)\end{array}$ & $\begin{array}{l}\text { NH } \\
(\mathrm{n}=6)\end{array}$ & $\begin{array}{l}\mathrm{NL} \\
(\mathrm{n}=24)\end{array}$ & $\begin{array}{l}\text { CYS } \\
(\mathrm{n}=8)\end{array}$ & \\
\hline Peak estradiol, pg/mL & $5.8^{\mathrm{a}} \pm 0.7$ & $6.0^{\mathrm{a}} \pm 1.1$ & $0.9^{b} \pm 0.6$ & $10.6^{\mathrm{c}} \pm 1.0$ & $<0.001$ \\
\hline Day of peak estradiol & $16.2 \pm 0.9$ & $16.8 \pm 1.6$ & $-^{2}$ & $19.3 \pm 1.4$ & 0.19 \\
\hline Peak follicle diameter, $\mathrm{mm}$ & $18.0^{\mathrm{ab}} \pm 0.8$ & $20.9^{\mathrm{a}} \pm 1.3$ & $15.6^{\mathrm{b}} \pm 0.7$ & $31.0 \pm 1.1$ & $<0.001$ \\
\hline Day of peak follicle diameter & $17.3^{\mathrm{a}} \pm 0.9$ & $20.0^{\mathrm{a}} \pm 1.5$ & $20.0^{\mathrm{a}} \pm 0.8$ & $28.3^{\mathrm{b}} \pm 1.3$ & $<0.001$ \\
\hline
\end{tabular}

${ }^{\mathrm{a}-\mathrm{c}}$ Means within a row with no common superscript letters differ $(P \leq 0.05)$.

${ }^{1} \mathrm{OV}=$ ovulatory, $\mathrm{NH}=$ nonovulatory high estradiol, $\mathrm{NL}=$ nonovulatory low estradiol, $\mathrm{CYS}=$ cyst.

${ }^{2}$ The NL cows did not have a distinct day of peak estradiol. Peak estradiol value for cows with NL follicles corresponds to circulating estradiol on day of peak follicle diameter.

nancy). Many studies have found hypoglycemia, hypoinsulinemia, and elevated NEFA to be associated with the postpartum anovulatory condition. We considered drenching with PPG during the transition period a potentially practical and useful method to increase transiently insulin and glucose and decrease NEFA on a daily basis from $d-10$ to 25 . Results of the current study indicate that daily drenching with PPG during the transition period had no beneficial impact on $\mathrm{LH}$ pulsatility, ovarian estradiol output, and the outcome of the first postpartum follicular wave, despite the improved EB status, insulin profile, and metabolite concentrations of these cows. Using a less frequent drenching schedule ( $300 \mathrm{~g}$ mixed in the diet from $\mathrm{d}-10$ until day of parturition, and administered as an oral drench on d 3, 6, 9, and 12 after parturition), Formigoni et al. (1996) observed an earlier return to cyclicity. Similarly, Miyoshi et al. (2001) observed an earlier onset of ovulatory activity when cows were administered a daily 500-

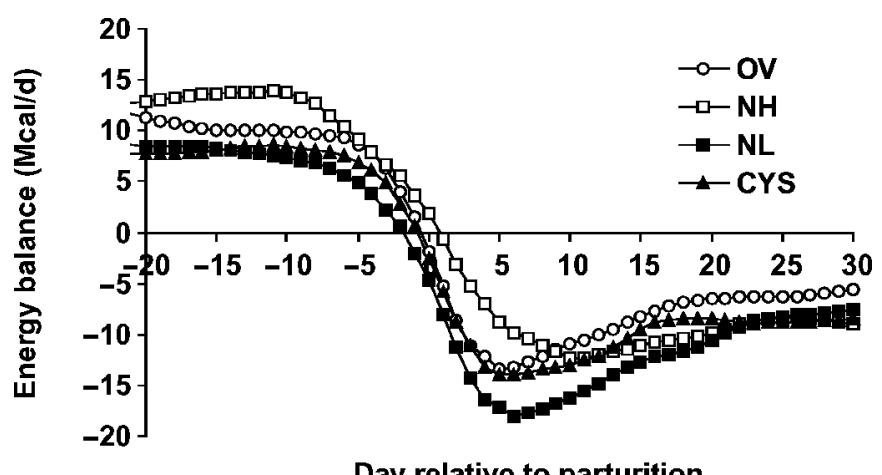

Day relative to parturition

Figure 5. The LOESS-smoothed curves of mean energy balance from $\mathrm{d}-10$ to 30 in cows with different follicle types during the first postpartum follicle wave. Significant effects of follicle type $(P<0.001)$ and follicle type $\times$ time $(P<0.05)$ were observed. The SEM were 0.46 , $0.77,0.39$, and $0.68 \mathrm{Mcal} / \mathrm{d}$ for ovulatory (OV), nonovulatory high estradiol (NH), nonovulatory low estradiol (NL), and cystic (CYS) cows, respectively.
$\mathrm{mL}$ PPG drench between $\mathrm{d} 7$ and 42 postpartum. In contrast, our results indicate that a single daily drench containing $500 \mathrm{~mL}$ of PPG did not impact any of the characteristics of the first postpartum follicle wave. This indicated that transient elevations in insulin and glucose and decreases in NEFA and the modest improvement in EB were insufficient to adequately stimulate the hypothalamic-pituitary-ovarian (HPO) axis.

The most interesting findings from the present study emerged after cows were categorized on the basis of follicle type. Cows with an ovulatory follicle are considered to have best adapted to lactation, as assessed by recovery of a fully functional HPO axis during recruitment and development of the first postpartum follicle wave. Cows with OV follicles had the most favorable EB, DMI, and hormonal and metabolic profiles, but differences were significant compared with only NL cows for most variables. The NH cows had the greatest DMI and EB during late pregnancy (d -21 to -8 ), but this trend did not continue postpartum. Cows that developed cysts were not different from the other groups for most variables measured. Therefore, all nonovulatory animals should not be considered as a similar physiological group, because there seems to be differences in the adaptive ability of these cows to the onset of lactation.

The NH cows represent an interesting group of anovulatory animals; follicle growth and estradiol output seemed identical to OV cows, but they failed to ovulate following a preovulatory-like rise in estradiol. Thus, the GnRH-LH pulse frequency necessary to generate a steroidogenically competent follicle seems intact, but their ability to induce an LH surge, or to ovulate in response to an LH surge, was impaired. Similar observations of an impaired LH surge feedback mechanism during NEB have been reported in fasted beef heifers (Mackey et al., 1999) and early lactating sheep (Wright et al., 1980). Estradiol production is reduced and returns to baseline values within $8 \mathrm{~h}$ after the peak in 

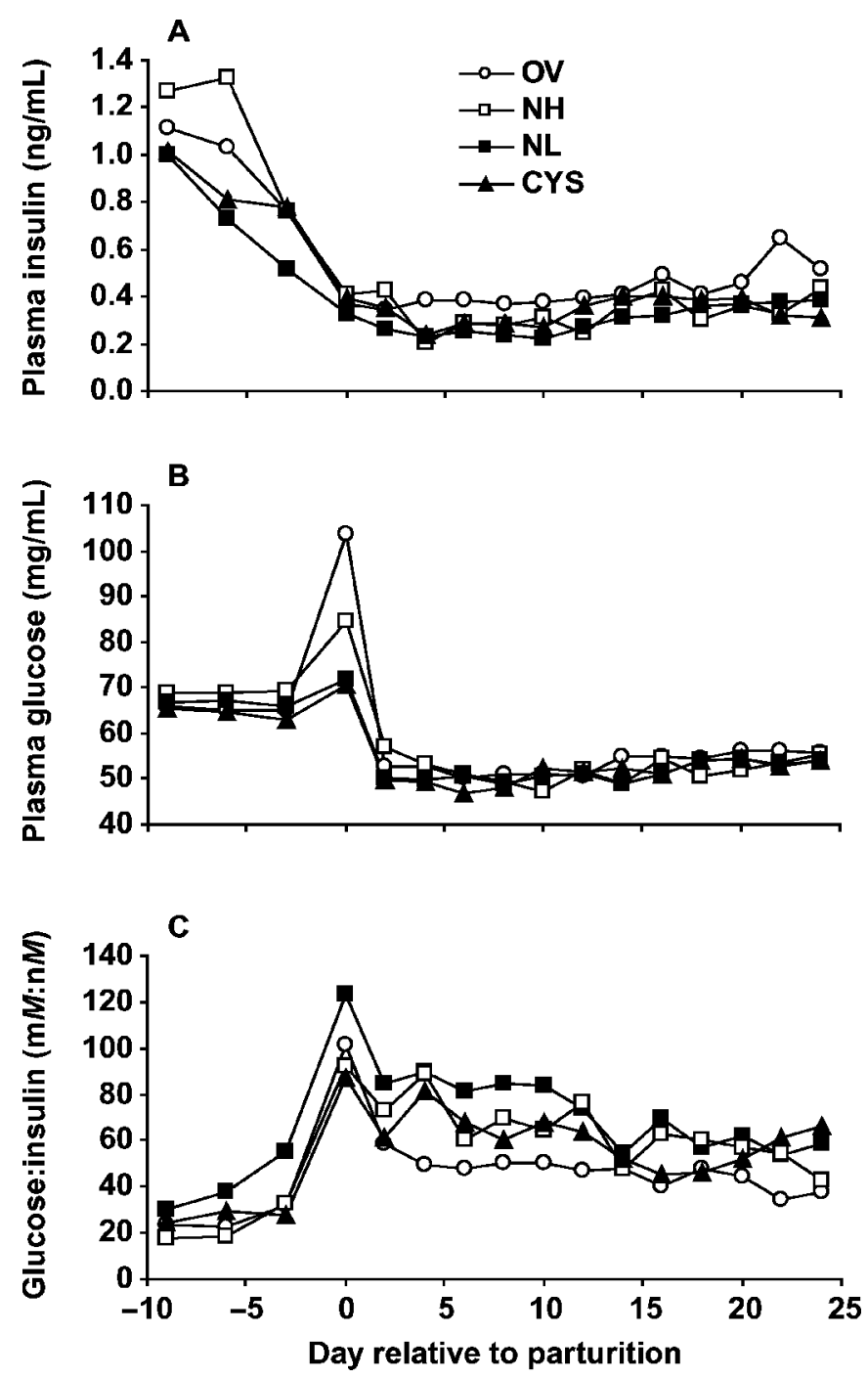

Figure 6. Profiles of circulating insulin, glucose, and the molar ratio of circulating glucose:insulin from $\mathrm{d}-10$ to 25 in cows having different follicle types during the first postpartum follicle wave. A) Plasma insulin concentrations were determined by radioimmunoassay in 3 prepartum samples, and every other day postpartum. A significant $(P<0.001)$ effect of follicle type was observed. The SEM were $0.03,0.04,0.02$, and $0.04 \mathrm{ng} / \mathrm{mL}$ for ovulatory $(\mathrm{OV})$, nonovulatory high estradiol (NH), nonovulatory low estradiol (NL), and cystic (CYS) cows, respectively; B) plasma concentrations of glucose were determined in 3 prepartum samples, and every other day postpartum. Significant effects of follicle type $(P<0.01)$ and follicle type by time $(P<0.001)$ were observed. The SEM were $0.7,1.2,0.6$, and $1.0 \mathrm{mg} /$ $\mathrm{dL}$ for $\mathrm{OV}, \mathrm{NH}, \mathrm{NL}$, and CYS cows, respectively; C) molar ratio of glucose:insulin in plasma. A significant $(P<0.001)$ effect of follicle type was observed. The SEM were 3.5, 5.7, 2.9, and 4.9 for $\mathrm{OV}, \mathrm{NH}$, NL, and CYS cows, respectively. Conversion factor used for glucose was $\mathrm{mg} / \mathrm{dL} \times 0.0554=\mathrm{m} M$, and for insulin $\mathrm{ng} / \mathrm{mL} \times 0.1744=\mathrm{n} M$ (molecular mass of bovine insulin $=5,733 \mathrm{kDa}$ ).

the LH surge in cows having normal follicles (Haughian et al., 2004). Based on the profiles of estradiol observed in $\mathrm{NH}$ cows, it is tempting to speculate that cows with a slow 3 - to 4-d reduction in the preovulatory-like estra-

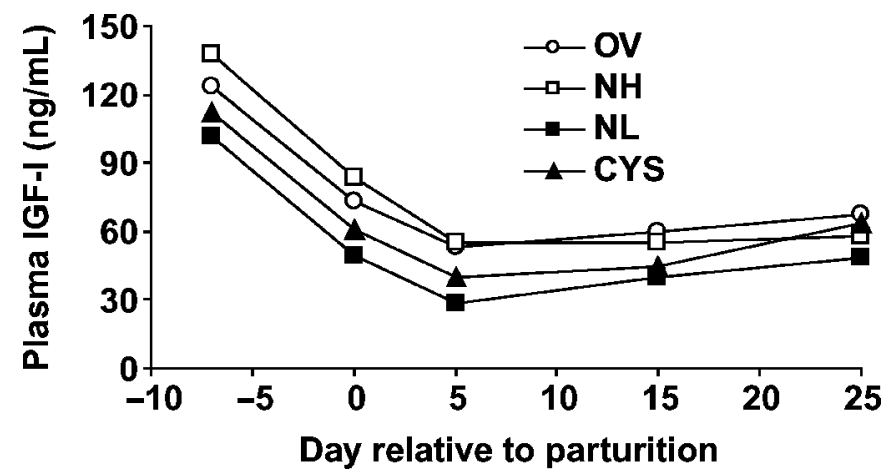

Figure 7. Plasma IGF-I from $d-7$ to 25 relative to parturition in cows having different follicle types during the first postpartum follicle wave. A significant $(P<0.01)$ effect of follicle type was observed. The SEM were $4.9,8.5,4.4$ and $7.4 \mathrm{ng} / \mathrm{mL}$ for ovulatory (OV), nonovulatory high estradiol (NH), nonovulatory low estradiol (NL), and cystic (CYS) cows, respectively.

diol peak failed to induce a GnRH-LH surge (hypothalamic lesion). Conversely, it is possible that the NH cows with a rapid reduction in estradiol did stimulate a GnRH-LH surge. Either the surge was inadequate to stimulate ovulation, but sufficient to shutdown estradiol synthesis, or alternatively, the surge was adequate, but ovarian responsiveness to LH was somehow blunted (hypothalamic or ovarian lesion, or both). Duffy et al. (2000) reported that early lactating beef cows exhibited an LH surge, but failed to ovulate. With only a single daily blood sample available, evidence of an LH surge was not detected in any of the cows failing to ovulate after exhibiting a preovulatory-like rise in estradiol (data not shown). The NH cows had greater prepartum (d -21 to -8) EB and DMI than any of the other groups,

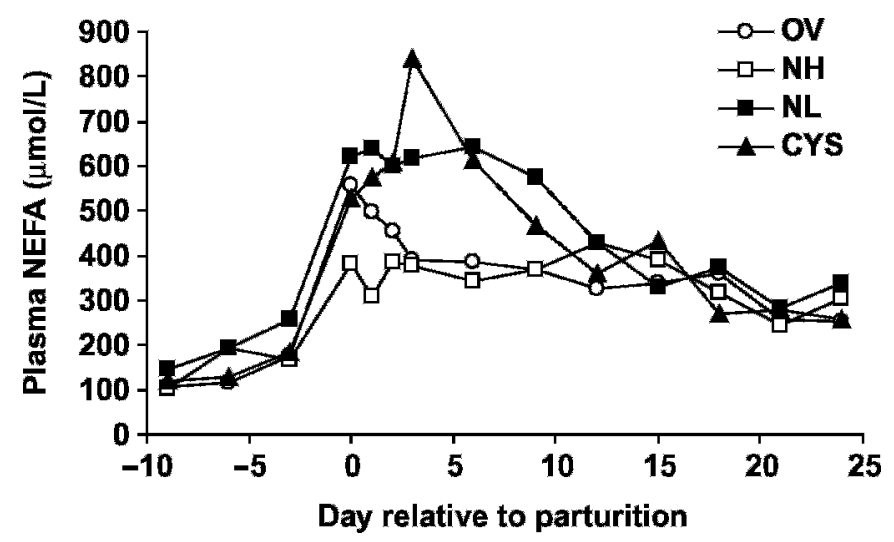

Figure 8. Plasma NEFA concentrations from $d-10$ to 25 relative to parturition in cows having different follicle types during the first postpartum follicle wave. A significant $(P<0.01)$ effect of follicle type was observed. The SEM were $5,9,4$, and $7 \mu \mathrm{mol} / \mathrm{l}$ for ovulatory (OV), nonovulatory high estradiol (NH), nonovulatory low estradiol (NL), and cystic (CYS) cows, respectively. 
Table 6. Summary of transition period energy balance (EB) and DMI in cows grouped on the basis of type of follicle observed during the first postpartum wave

\begin{tabular}{|c|c|c|c|c|}
\hline \multirow[b]{2}{*}{ Item } & \multicolumn{4}{|c|}{ Follicle type $^{1}$} \\
\hline & OV & $\mathrm{NH}$ & NL & CYS \\
\hline \multicolumn{5}{|c|}{ Day -21 to -8} \\
\hline $\mathrm{EB}, \mathrm{Mcal} / \mathrm{d}$ & $10.3^{\mathrm{a}} \pm 0.6$ & $13.6^{\mathrm{b}} \pm 0.9$ & $8.0^{\mathrm{c}} \pm 0.5$ & $8.2^{\mathrm{ac}} \pm 0.8$ \\
\hline DMI, kg/d & $16.3^{\mathrm{a}} \pm 0.4$ & $18.3^{b} \pm 0.6$ & $14.9^{\mathrm{c}} \pm 0.3$ & $15.3^{\mathrm{ac}} \pm 0.5$ \\
\hline \multicolumn{5}{|l|}{ Day -7 to -1} \\
\hline EB, Mcal/d & $7.9^{\mathrm{a}} \pm 0.8$ & $8.0^{\mathrm{a}} \pm 1.4$ & $3.8^{\mathrm{b}} \pm 0.7$ & $5.7^{\mathrm{ab}} \pm 1.2$ \\
\hline DMI, kg/d & $14.4^{\mathrm{a}} \pm 0.5$ & $14.3^{\mathrm{a}} \pm 0.9$ & $11.9^{b} \pm 0.4$ & $13.3^{\mathrm{ab}} \pm 0.8$ \\
\hline \multicolumn{5}{|l|}{ Day 0 to 30} \\
\hline $\mathrm{EB}, \mathrm{Mcal} / \mathrm{d}$ & $-8.3^{\mathrm{a}} \pm 0.8$ & $-9.0^{\mathrm{ab}} \pm 1.2$ & $-12.2^{\mathrm{b}} \pm 0.6$ & $-10.1^{\mathrm{ab}} \pm 1.1$ \\
\hline DMI, kg/d & $20.3^{a} \pm 0.5$ & $19.7^{\mathrm{ab}} \pm 0.8$ & $18.1^{\mathrm{b}} \pm 0.4$ & $19.7^{\mathrm{ab}} \pm 0.7$ \\
\hline
\end{tabular}

${ }^{\mathrm{a}-\mathrm{c}}$ Means within a row not sharing a common superscript letter differ $(P \leq 0.05)$.

${ }^{1} \mathrm{OV}=$ ovulatory, $\mathrm{NH}=$ nonovulatory high estradiol, $\mathrm{NL}=$ nonovulatory low estradiol, $\mathrm{CYS}=$ cyst.

but had a longer duration of declining EB compared with OV cows.

Cows with cysts had adequate GnRH-LH pulse frequency to stimulate a preovulatory-like rise in estradiol, but failed to ovulate. Etiology of cystic ovarian disease remains unresolved, but it is clear that the positive feedback mechanism of estradiol required to stimulate an LH surge is dysfunctional (Garverick, 1997), possibly caused by low circulating concentrations of progesterone acting to antagonize estradiol action at the hypothalamus and pituitary (Silvia et al., 2002). Of the 8 cows that developed cysts in the current study, 2 cows differed from the remaining 6 ; both cows displayed a normal preovulatory-like rise in estradiol followed by a rapid (within $24 \mathrm{~h}$ ) return to baseline concentrations. Similar to normal follicles, estradiol synthesis is reduced in cows with cystic follicles following an LH surge (Garverick, 1997). A new follicle wave emerged in both cows within $4 \mathrm{~d}$ of the peak of the preovulatory-like rise in estradiol in the presence of the growing cyst, indicating that a surge in FSH also likely occurred (Fig-

Table 7. Multiple logistic regression model predicting the probability of the first follicle wave being ovulatory

\begin{tabular}{|c|c|c|}
\hline Model for ovulatory follicles & Coefficient & $P$-value \\
\hline Intercept & -14.6867 & 0.005 \\
\hline Duration of declining $\mathrm{EB}^{2}$ & -0.3282 & 0.013 \\
\hline Insulin, d 0 to $25 \mathrm{AUC}^{1}$ & 0.6008 & 0.015 \\
\hline DMI, $\mathrm{d}-7$ to -1 AUC & 0.0963 & 0.032 \\
\hline Glucose, d 0 & 0.0560 & 0.031 \\
\hline \multicolumn{3}{|l|}{ Model assessment } \\
\hline$(-2 \log \mathrm{L}) \chi^{2}$ & \multicolumn{2}{|c|}{35.9} \\
\hline$P>\chi^{2}$ & \multicolumn{2}{|c|}{$<0.0001$} \\
\hline Concordant, $\%$ & \multicolumn{2}{|c|}{92.9} \\
\hline Discordant, \% & \multicolumn{2}{|c|}{6.9} \\
\hline Tied, \% & \multicolumn{2}{|c|}{0.2} \\
\hline Somers' D: & \multicolumn{2}{|c|}{0.86} \\
\hline
\end{tabular}

${ }^{1} \mathrm{AUC}=$ Area under the curve.

${ }^{2} \mathrm{~EB}=$ Energy balance. ure 4E). Both cows also had an increase in progesterone to approximately $0.3 \mathrm{ng} / \mathrm{mL}$ within $7 \mathrm{~d}$ of the peak in estradiol, implying luteinization of the cyst (progesterone $<0.05 \mathrm{ng} / \mathrm{mL}$ on day of peak estradiol). Based on this evidence, we propose that these 2 cows had a GnRH-LH surge, but either the surge was inadequate to cause ovulation, or the follicle was unresponsive to an apparently normal LH surge. Rather than ovulate or become atretic, follicles continued to grow and develop into cysts. Again, with a single daily blood sample, evidence of an LH surge was not detected.

The NL cows failed to produce any significant quantities of estradiol, and none displayed a preovulatory-like rise in circulating estradiol. This likely reflects inadequate $\mathrm{GnRH}-\mathrm{LH}$ pulse frequency; thus, these cows might represent the poorest adaptation to lactation and regeneration of a functional HPO axis. The NL cows had the poorest DMI and the least favorable EB and hormonal and metabolic profiles. It is interesting to note that $\mathrm{EB}$ and DMI in the NL cows were inferior to those of the $\mathrm{OV}$ and $\mathrm{NH}$ groups as early as $3 \mathrm{wk}$ before parturition.

Insulin also plays a role in ovarian steroidogenesis. Insulin receptors are widely distributed throughout all ovarian compartments, including granulosa, thecal, and stromal tissues (Poretsky and Kalin, 1987). In vitro studies have shown that insulin directly stimulates both mitosis and steroid production of cultured bovine granulosa cells (Gutierrez et al., 1997) and luteal cells (Mamluk et al., 1999). In addition, insulin increases steroidogenesis in response to gonadotropins in vitro (Stewart et al., 1995; Silva and Price, 2002). Early postpartum dairy cows fed diets designed to increase circulating insulin concentrations had an earlier onset of estrous cycles and more favorable conception rates at first service (Gong et al., 2002). We have recently examined the role of circulating insulin on $\mathrm{LH}$ release and circulating steroids during the first postpartum follicle 
wave. A 2.6-fold elevation in circulating insulin resulted in increased circulating estradiol, without any apparent changes in LH pulsatility (Butler et al., 2004). Circulating insulin was elevated in OV cows following parturition in the current study, and may have played a role in determining the fate of the first postpartum follicle wave.

A critical facet of successful onset of lactation is the reduced responsiveness of muscle and adipose tissue to insulin, allowing greater nutrient uptake by the mammary gland in support of milk synthesis (Bauman and Elliot, 1983; Bell, 1995; Bauman, 2000). We observed little variation between the different follicle-type groups in circulating glucose during the postpartum experimental period. Circulating insulin, however, was greatest in the future OV cows, resulting in this group having the lowest glucose to insulin ratio (Figure 6B and $6 \mathrm{C}$ ). Hence, OV cows had greater circulating insulin per unit of glucose, especially compared with NL cows. Pancreatic insulin release in response to propionate or glucose in dairy cows is less during lactation than during the nonlactating state (Lomax et al., 1979; Sano et al., 1993). In the current study, OV cows had greater DMI than NL cows during the duration of the study, presumably increasing propionate supply and pancreatic insulin secretion. Insulin secretion in response to intravenous infusion of glucose was greater in cows displaying normal estrous cycles than in cystic cows (Opsomer et al., 1999). Without sensitive measures of insulin secretion and glucose disposal, however, we cannot definitively state whether the differences observed in plasma insulin are attributable to differences in pancreatic insulin secretion, insulin clearance, or peripheral tissue insulin resistance.

On the day of parturition, the prospective OV cows displayed a marked elevation in glucose (Figure 6B). It is possible that the difference merely reflects closer proximity between collection of blood samples from this group and timing of the increase in glucose associated with parturition. Given the relatively large number of cows in the groups, however, this seems unlikely. It may also be indicative of greater stores of glycogen in these cows, or mobilization of the glycogen stores in response to glycogenolytic stimuli. A further possible interpretation is that it reflects a greater degree of peripheral tissue insulin resistance, and thus a smaller pool of tissues available to utilize the glucose in circulation.

Cows with an ovulatory follicle had reduced liver TG concentration compared with nonovulatory cows, in agreement with preliminary findings by Marr et al. (2002). Because cows with ovulatory follicles also had less NEFA, this represents reduced mobilization of fatty acids from adipose tissue for uptake and esterifi- cation by the liver. In addition, hepatic oxidation of fatty acids may have been enhanced, and if this were the case, would present an obvious advantage. Efficacy of laying down adipose stores during nutrient excess is contingent upon these stores being used for energy production during nutrient deficit. There is little advantage to mobilizing TG from adipose tissue only to reesterify the free fatty acids back to TG in the liver. Regulation of periparturient hepatic mitochondrial and peroxisomal $\beta$-oxidation capacity is an area of growing interest (Drackley et al., 2001).

\section{CONCLUSIONS}

Drenching with PPG during the transition period had no positive or negative effects on the fate of the first postpartum follicle wave, despite apparent beneficial effects on metabolic status. Results of the current study indicate once again that EB is a key regulator of reproductive function. It has been suggested that DMI during late pregnancy plays a role in "programming" susceptibility to periparturient metabolic disorders (Grummer, 1995). Likewise, results of the current study indicate that DMI, and accordingly EB, during late pregnancy may play a pivotal role in predetermining the functionality of the HPO axis, and hence, fate of the first postpartum follicle wave. Further work with sensitive measures of pancreatic insulin release in response to an insulin secretagogue and peripheral insulin responsiveness are required to examine whether differences exist between cows with ovulatory and nonovulatory follicles. In addition, identification of factors that stimulate DMI and upregulate hepatic $\beta$-oxidation capacity during the transition period would have immediate beneficial impact.

\section{ACKNOWLEDGMENTS}

Partial support of this study was provided by funds allocated to USDA regional project NE-161. We are grateful to B. Berggren-Thomas, T. Janda, T. Muscato, and M. Partridge for technical assistance, and the farm staff at the Cornell University Dairy Teaching and Research Center for care of the cows. Antisera to human IGF-1 was obtained through National Hormone and Peptide Program, National Institute of Diabetes and Digestive and Kidney Diseases, and A. F. Parlow. Antisera to bovine LH was a generous gift from R. B. Staigmiller. S. T. Butler was a recipient of a Walsh fellowship from Teagasc (The Irish Agriculture and Food Development Authority) in support of his Ph.D. program.

\section{REFERENCES}

Bauman, D. E. 2000. Regulation of nutrient partitioning during lactation: Homeostasis and homeorhesis revisited. Pages 311-327 in 
Ruminant Physiology: Digestion, Metabolism, Growth and Reproduction. Proc. 9th Int. Symp. Rumin. Phys. P. J. Cronje, ed. CABI Publishing, New York, NY.

Bauman, D. E., and J. M. Elliot. 1983. Control of nutrient partitioning in lactating ruminants. Pages 437-468 in Biochemistry of Lactation. T. B. Mepham, ed. Elsevier, Amsterdam, The Netherlands.

Beam, S. W., and W. R. Butler. 1999. Effects of energy balance on follicular development and first ovulation in postpartum dairy cows. J. Reprod. Fertil. Suppl. 54:411-424.

Bell, A. W. 1995. Regulation of organic nutrient metabolism during transition from late pregnancy to early lactation. J. Anim. Sci. 73:2804-2819.

Bucholtz, D. C., N. M. Vidwans, C. G. Herbosa, K. K. Schillo, and D. L. Foster. 1996. Metabolic interfaces between growth and reproduction. V. Pulsatile luteinizing hormone secretion is dependent on glucose availability. Endocrinology 137:601-607.

Butler, S. T., A. L. Marr, S. H. Pelton, R. P. Radcliff, M. C. Lucy, and W. R. Butler. 2003. Insulin restores GH responsiveness during lactation-induced negative energy balance in dairy cattle: Effects on expression of IGF-I and GH receptor 1A. J. Endocrinol. 176:205-217.

Butler, S. T., S. H. Pelton, and W. R. Butler. 2004. Insulin increases $17 \beta$-estradiol production by the dominant follicle of the first postpartum follicle wave in dairy cows. Reproduction 127:537-545.

Butler, W. R. 2003. Energy balance relationships with follicular development, ovulation and fertility in postpartum dairy cows. Livest. Prod. Sci. 83:211-218.

Butler, W. R., and R. D. Smith. 1989. Interrelationships between energy balance and postpartum reproductive function in dairy cattle. J. Dairy Sci. 72:767-783.

Christensen, J. O., R. R. Grummer, F. E. Rasmussen, and S. J. Bertics. 1997. Effect of method of delivery of propylene glycol on plasma metabolites of feed restricted cattle. J. Dairy Sci. 80:563-568.

Darwash, A. O., G. E. Lamming, and J. A. Woolliams. 1997. The phenotypic association between the interval to post-partum ovulation and traditional measures of fertility in dairy cattle. Anim. Sci. 65:9-16.

Diskin, M. G., D. R. Mackey, J. F. Roche, and J. M. Sreenan. 2003. Effects of nutrition and metabolic status on circulating hormones and ovarian follicle development in cattle. Anim. Reprod. Sci. 78:345-370.

Drackley, J. K., T. R. Overton, and G. N. Douglas. 2001. Adaptations of glucose and long-chain fatty acid metabolism in liver of dairy cows during the periparturient period. J. Dairy Sci. 84(E. Suppl.):E100-E112.

Duffy, P., M. A. Crowe, M. P. Boland, and J. F. Roche. 2000. Effect of exogenous LH pulses on the fate of the first dominant follicle in postpartum beef cows nursing calves. J. Reprod. Fertil. 118:9-17.

Folch, J., M. Lees, and G. H. Sloane Stanley. 1957. A simple method for the isolation and purification of total lipids from animal tissues. J. Biol. Chem. 226:497-509.

Formigoni, A., M. C. Cornil, A. Prandi, A. Mordenti, A. Rossi, D. Portetelle, and R. Renaville. 1996. Effect of propylene glycol supplementation around parturition on milk yield, reproduction performance and some hormonal metabolic characteristics in dairy cows. J. Dairy Res. 63:11-24.

Foster, L. B., and R. T. Dunn. 1973. Stable reagents for determination of serum triglycerides by a colorimetric Hantzsch condensation method. Clin. Chem. 19:338-340.

Garverick, H. A. 1997. Ovarian follicular cysts in dairy cows. J. Dairy Sci. 80:995-1004.

Gong, J. G., W. J. Lee, P. C. Garnsworthy, and R. Webb. 2002. The effect of dietary induced increases in circulating insulin concentrations during the early postpartum period on reproductive function in dairy cows. Reproduction 123:419-427.

Grummer, R. R. 1995. Impact of changes in organic nutrient metabolism on feeding the transition dairy cow. J. Anim. Sci. 73:2820-2833.

Grummer, R. R., J. C. Winkler, S. J. Bertics, and V. A. Studer. 1994. Effect of propylene glycol dosage during feed restriction on metabolites in blood of prepartum Holstein heifers. J. Dairy Sci. 77:3618-3623.
Gutierrez, C. G., B. K. Campbell, and R. Webb. 1997. Development of a long-term bovine granulosa cell culture system: Induction and maintenance of estradiol production, response to follicle-stimulating hormone, and morphological characteristics. Biol. Reprod. 56:608-616.

Haughian, J. M., O. J. Ginther, K. Kot, and M. C. Wiltbank. 2004. Relationships between FSH patterns and follicular dynamics and the temporal associations among hormones in natural and GnRHinduced gonadotropin surges in heifers. Reproduction 127:23-33.

I'Anson, H., D. L. Foster, G. R. Foxcroft, and P. J. Booth. 1991. Nutrition and reproduction. Oxford Review Reprod. Biol. 13:239-311.

Littell, R. C., P. R. Henry, and C. B. Ammerman. 1998. Statistical analysis of repeated measures data using SAS procedures. J. Anim. Sci. 76:1216-1231.

Lomax, M. A., G. D. Baird, C. B. Mallinson, and H. W. Symonds. 1979. Differences between lactating and non-lactating dairy cows in concentration and secretion rate of insulin. Biochem. J. 180:281-289.

Mackey, D. R., J. M. Sreenan, J. F. Roche, and M. G. Diskin. 1999. Effect of acute nutritional restriction on incidence of anovulation and periovulatory estradiol and gonadotropin concentrations in beef heifers. Biol. Reprod. 61:1601-1607.

Mamluk, R., Y. Greber, and R. Meidan. 1999. Hormonal regulation of messenger ribonucleic acid expression for steroidogenic factor1 , steroidogenic acute regulatory protein, and cytochrome P450 side-chain cleavage in bovine luteal cells. Biol. Reprod. 60:628634.

Marr, A. L., M. S. Piepenbrink, T. R. Overton, M. C. Lucy, and W. R. Butler. 2002. The somatotrophic axis and lipid metabolism in transition dairy cows in relation to timing of first postpartum ovulation. J. Dairy Sci. 85(Suppl. 1):66. (Abstr.)

McGuire, M. A., D. E. Bauman, D. A. Dwyer, and W. S. Cohick. 1995. Nutritional modulation of the somatotropin/insulin-like growth factor system: response to feed deprivation in lactating cows. J. Nutr. 125:493-502.

Miyoshi, S., J. L. Pate, and D. L. Palmquist. 2001. Effects of propylene glycol drenching on energy balance, plasma glucose, plasma insulin, ovarian function and conception in dairy cows. Anim. Reprod. Sci. 68:29-43.

National Research Council. 2001. Nutrient Requirements of Dairy Cattle. Natl. Acad. Sci., Washington, DC.

Nielsen, N. I., and K. L. Ingvartsen. 2004. Propylene glycol for dairy cows: A review of the metabolism of propylene glycol and its effects on physiological parameters, feed intake, milk production and risk of ketosis. Anim. Feed Sci. Technol. 115:191-213.

Ohkura, S., T. Ichimaru, F. Itoh, S. Matsuyama, and H. Okamura. 2004. Further evidence for the role of glucose as a metabolic regulator of hypothalamic gonadotropin-releasing hormone pulse generator activity in goats. Endocrinology 145:3239-3246.

Opsomer, G., T. Wensing, H. Laevens, M. Coryn, and A. de Kruif. 1999. Insulin resistance: The link between metabolic disorders and cystic ovarian disease in high yielding dairy cows? Anim. Reprod. Sci. 56:211-222.

Pickett, M. M., M. S. Piepenbrink, and T. R. Overton. 2003. Effects of propylene glycol or fat drench on plasma metabolites, liver composition, and production of dairy cows during the periparturient period. J. Dairy Sci. 86:2113-2121.

Poretsky, L., and M. F. Kalin. 1987. The gonadotropic function of insulin. Endocr. Rev. 8:132-141.

Sano, H., S. Narahara, T. Kondo, A. Takahashi, and Y. Terashima. 1993. Insulin responsiveness to glucose and tissue responsiveness to insulin during lactation in dairy cows. Domest. Anim. Endocrinol. 10:191-197.

Savio, J. D., M. P. Boland, and J. F. Roche. 1990. Development of dominant follicles and length of ovarian cycles in post-partum dairy cows. J. Reprod. Fertil. 88:581-591.

Schneider, J. E., and G. N. Wade. 2000. Inhibition of reproduction in service of energy balance. Pages 35-82 in Reproduction in Context: Social and Environmental Influences on Reproductive 
Physiology and Behavior. K. Wallen and J. E. Schneider, ed. Massachusetts Institute of Technology, Cambridge, MA.

Silva, J. M., and C. A. Price. 2002. Insulin and IGF-I are necessary for FSH-induced cytochrome P450 aromatase but not cytochrome P450 side-chain cleavage gene expression in oestrogenic bovine granulosa cells in vitro. J. Endocrinol. 174:499-507.

Silvia, W. J., T. B. Hatler, A. M. Nugent, and L. F. Laranja da Fonseca. 2002. Ovarian follicular cysts in dairy cows: An abnormality in folliculogenesis. Domest. Anim. Endocrinol. 23:167-177.

Stewart, R. E., L. J. Spicer, T. D. Hamilton, and B. E. Keefer. 1995. Effects of insulin-like growth factor I and insulin on proliferation and on basal and luteinizing hormone-induced steroidogenesis of bovine thecal cells: Involvement of glucose and receptors for insulin-like growth factor I and luteinizing hormone. J. Anim. Sci. 73:3719-3731.
Studer, V. A., R. R. Grummer, and S. J. Bertics. 1993. Effect of prepartum propylene glycol administration on periparturient fatty liver in dairy cows. J. Dairy Sci. 76:2931-2939.

Wade, G. N., J. E. Schneider, and H. Y. Li. 1996. Control of fertility by metabolic cues. Am. J. Physiol. 270:E1-E19.

Westwood, C. T., I. J. Lean, and J. K. Garvin. 2002. Factors influencing fertility of Holstein dairy cows: A multivariate description. J. Dairy Sci. 85:3225-3237.

Wiltbank, M. C., A. Gumen, and R. Sartori. 2002. Physiological classification of anovulatory conditions in cattle. Theriogenology 57:21-52.

Wright, P. J., P. E. Geytenbeek, I. J. Clark, and J. K. Findlay. 1980. Pitutary responsiveness to LH-RH, the occurrence of oestradiol17 beta-induced LH-positive feedback and the resumption of oestrous cycles in ewes post partum. J. Reprod. Fertil. 60:171-176. 